\title{
Assessment of the level of health literacy of drug users in the Primary Health Care of the Brazilian Unified Health System
}

\author{
Avaliação do nível de alfabetização em saúde de usuários de medicamentos na Atenção Básica à \\ Saúde do Sistema Único de Saúde \\ Evaluación del nivel de alfabetización en salud de los consumidores de medicamentos en la \\ Atención Primaria de Salud del Sistema Único de Salud
}

Received: 08/14/2021 | Reviewed: 08/19/2021 | Accept: 08/24/2021 | Published: 08/26/2021

\begin{abstract}
Patients' knowledge and awareness of their disease and medication (health literacy) are essential to ensure treatment effectiveness. This work analyzed the health literacy (HL) level of users of the Brazilian Unified Health System (SUS) in Diadema city (SP) and its consequences concerning the rational use of prescribed medication. A total of 1,121 SUS users were interviewed and descriptive and inferential analyses were performed. Bivariate analyses estimated the crude odds ratio. A logistic regression model was developed, and the results were presented as adjusted odds ratio. Almost half of the sample did not know the name of the drug, $20 \%$ did not know the reason for using it, $14 \%$ did not know how to use the drug, $71 \%$ declared that they were unaware of the drug's adverse reactions, $21.3 \%$ believed that the drug did not cause any adverse reaction, and only $7.7 \%$ considered that the drug could cause some problem and $92 \%$ claimed not to have asked the doctor anything about this matter. The data show an inadequate level of HL of SUS users concerning basic information about the prescribed drug and a potential risk arising from the drug's misuse, considering the patient's lack of familiarity with the medication and their pathology and poor interaction with the health professional. Keywords: Health literacy; SUS; Prescribed medication; Drug's misuse; Patients 'knowledge; Rational use of medicine.
\end{abstract}

\section{Resumo}

O conhecimento e a conscientização dos pacientes sobre sua doença e seus medicamentos (Alfabetização em Saúde) são essenciais para garantir a eficácia do tratamento. Este trabalho analisou o nível de alfabetização em saúde (AS) de usuários do Sistema Único de Saúde (SUS) na cidade de Diadema (SP) e suas consequências no uso racional de medicamentos prescritos. Foram entrevistados 1.121 usuários do SUS e realizadas análises descritivas e inferenciais. As análises bivariadas estimaram o odds ratio bruto. Um modelo de regressão logística foi desenvolvido e os resultados ajustados como odds ratio. Quase metade da amostra não sabia o nome do medicamento, $20 \%$ não sabiam o motivo do seu uso, $14 \%$ não sabiam como usar o medicamento, $71 \%$ afirmaram não conhecer as reações adversas do medicamento , 21,3\% acreditavam que o medicamento não causava reação adversa e apenas 7,7\% consideraram que o medicamento poderia causar problema e $92 \%$ afirmaram não ter perguntado ao médico nada sobre o assunto. Os dados mostraram um nível inadequado de AS dos usuários do SUS quanto às informações básicas sobre o medicamento prescrito e um potencial risco decorrente do uso indevido do medicamento, considerando a falta de familiaridade do paciente com o medicamento e sua patologia e a pouca interação com o profissional de saúde.

Palavras-chave: Alfabetização em saúde; SUS; Medicamentos prescritos; Uso indevido de medicamentos; Conhecimento do paciente; Uso racional do medicamento.

\section{Resumen}

El conocimiento y la conciencia de los pacientes sobre su enfermedad y su medicación (alfabetización en salud) son esenciales para garantizar la eficacia del tratamiento. Este trabajo analizó el nivel de alfabetización en salud de los usuarios del SUS en una ciudad del estado de São Paulo y sus consecuencias en el uso racional de la medicación prescrita. Se entrevistó a un total de 1.121 usuarios del SUS. Se realizaron análisis descriptivos e inferenciales. Los análisis bivariados estimaron la razón de probabilidades bruta. Se desarrolló un modelo de regresión logística y los resultados se presentaron como razón de probabilidades ajustada. Casi la mitad de la muestra no conocía el nombre del fármaco, el $20 \%$ no sabía el motivo de su uso, el 14\% no sabía cómo utilizar el fármaco, el $71 \%$ declaró que desconocía 
las reacciones adversas del fármaco, 21,3 El\% creía que el fármaco no provocaba ninguna reacción adversa, y solo el $7,7 \%$ consideraba que el fármaco podía ocasionar algún problema y el $92 \%$ afirmaba no haberle preguntado nada al médico sobre este asunto. Los datos muestran un nivel inadecuado de AS de los usuarios del SUS con respecto a la información básica sobre el medicamento prescrito y un riesgo potencial derivado del uso indebido del medicamento, considerando la falta de familiaridad del paciente con el medicamento y su patología y la mala interacción con el profesional de la salud.

Palabras clave: Alfabetización en salud; SUS; Medicamentos recetados; Uso indebido de medicamentos; Conocimiento de los pacientes; Uso racional de la medicación.

\section{Introduction}

There is no denying the advance that medicines have brought to humanity, increasing life expectancy, eradicating certain diseases, bringing social and economic benefits. However, although medications are essential instruments for health recovery, they are not without risk and can lead to severe adverse reactions when misused, making them a significant public health problem globally (Yevstigneev et al, 2015; Ofori-Asenso \& Agyeman, 2016)

The WHO estimates that more than half of all medications are prescribed, dispensed, or sold inappropriately and that half of all patients fail to take them correctly. The overuse, underuse, or misuse of medicines results in squandering scarce resources and widespread health hazards (WHO, 2002; Calikoglu et al, 2019).

A total of 565,271 poisoning cases were reported in Brazil from 2010 to 2017, and the medication was the toxic agent in $52.8 \%$ of them (Andrade et al., 2020). Some authors claim that insufficient or even erroneous knowledge regarding the prescribed medication can lead to the incorrect use of the medication and the ensuing consequences, which can range from lower efficacy to increased hospitalization (Visscher et al., 2021).

One of the fundamental principles in health, which can prevent or reduce this condition, is the patient's knowledge and awareness of their disease and the medication they use. These are essential attributes for the patient to commit to their treatment, which is manifested, among other initiatives, through the correct use of medication (Alshammari, 2016),

The acquisition of this knowledge is linked to the concept of health literacy, which is defined as a set of individual skills that allow people to acquire and apply information in self-care and make decisions about their health care (Parnell et al., 2019). These skills are influenced by factors such as culture, educational level, cognitive abilities, age, and physical condition (Tae et al., 2016; Bosch-Lenders et al., 2016). Health literacy also encompasses skills needed to act within the healthcare environment, including patient interactions with healthcare professionals. Some evidence shows that individuals with limited health literacy have worse outcomes, including poor adherence to treatment, more frequent hospitalizations, and higher mortality than those with an adequate level of health literacy, besides higher health costs and lack of control over chronic diseases (Matsuyama et al, 2011; Cajita et al., 2015; Dunn \& Conrad, 2018).

However, difficulties in managing the drug therapy itself are not an uncommon phenomenon. In the U.S., for example, more than a third of the population does not have the necessary skills to understand health information, make health care decisions, or follow medication instructions (Hersh et al., 2015). Soorensen et al. (2015) compared the level of health literacy between eight European countries and concluded that the level was inadequate in more than $10 \%$ of the population interviewed, ranging from $1.8 \%$ to $26.9 \%$ between countries.

Brazil has produced few works on the health literacy theme. However, the particularity of the Brazilian public health system justifies research on this subject. Brazil's public health system is known as the Unified Health System (SUS) (Pasternak, 2018). It was established in 1990 in response to the demand of the 1988 Brazilian Constitution that defined health as a universal right and under the responsibility of the State (Castro et al, 2019). These are bold and challenging principles in a large country, extremely unequal in social, economic, and cultural terms. However, the SUS has been facing difficulties due to the underfunding 
to which it has been submitted for years (Massuda, 2018, 2020) which has not cooperated in reducing health care inequality (Mendez et al, 2018).

Most of the population, especially the most disadvantaged groups and those who do not have access to private health plans, rely on the SUS as their only access to medical care and medicines (Castro et al, 2019). However, this demand has been growing, given the impoverishment of the Brazilian population that began in 2014 (Balassiano, 2020) a situation that the severity of the COVID-19 pandemic has aggravated. Brazil has 14 million unemployed and 24 million people in the poverty range (Bastos, 2021). This situation has led to a greater demand from the SUS, which can contribute to harming the work developed in the public health network, including the activities performed by health professionals before dispensing drugs, such as the transfer of basic information about the medication to the patient clearly and with accessible language (Araujo et al., 2008). Also, access to PHC services and care in the SUS occurs through Primary Health Care. In this context, health education is among the various attributions of the pharmacist, which has a direct interface with Health Literacy. Besides counseling on how to use the medication, care is patient-centered to meet their individual needs. Sometimes, the pharmacist uses playful

tools, such as pictures or colors, to guide the drug user regarding the doses and dosage (Johnson et al., 2013; Castro et al., 2019).

Patients' level of misinformation about the medication can lead them to become disinterested in the treatment or even change it according to their convenience, which may lead to the ineffectiveness of the proposed therapy (Cajita et al., 2015, Calikoglu et al, 2019; Marciano et al., 2019). Thus, this study aimed to verify the level of health literacy of patients attending the SUS primary health network in the city of Diadema regarding the medication prescribed to them and how this knowledge interferes with the rational use of the medication. Patients' evaluation of this information can contribute to strategies to be developed in the public health network in Diadema, which is in high demand due to the characteristics of its population.

\section{Methodology}

This research was performed in the city of Diadema due to some of its particularities: it is located in the state of São Paulo, in the Great ABCD region, together with the cities of Santo André, São Bernardo, São Caetano. Of this hub, Diadema is the city with the lowest per capta GDP (per capta Gross Domestic Product). When compared to São Caetano, the wealthiest city in the complex, Diadema's per capta GDP is about 3.5 times lower) with significant use of essential public health services offered by the municipality (PNAD, 2019). It has about 4501,000 inhabitants with an HDI (Human Development Index) of 0.757, the lowest in the region (IBGE, 2010).

PHC selection criteria (Primary Health Care unit): With the participation of the Municipal Health Secretariat of Diadema, approximately $20 \%$ of the PHC units were selected and identified, equivalent to four of the 20 existing in Diadema. The choice respected the location and socioeconomic conditions of ea'ch region of the city; that is, the different regions of Diadema were considered.

Questionnaire: A questionnaire was created with questions related to the patient's knowledge of the prescribed medication, such as drug name, the reason for use, and adverse events. Notably, one of the questions addressed to the respondent was "what is the medication for?". Then, the respondent's answer was compared with the information contained in the medicine package insert and confirmed whether it was correct or not.

Sample recruitment: The implementation of this project started only after the Municipal Health Secretariat of Diadema's authorization through an official document, allowing access to the PHC. The survey participants were those who agreed to answer a questionnaire that took about 5 to 10 minutes to complete. The recruitment of respondents was carried out respecting the two operating shifts of the PHC (morning and afternoon). They were approached soon after the drug was dispensed 
at the PHC, which was considered the most appropriate time, bearing that the patient has completed the cycle (medical appointment, prescription, and dispensing) and, theoretically, should be informed about the medication that would be used.

Number of participants and rejection rate: The sample consisted of a $\mathrm{N}_{\text {total }}$ of 1,121 respondents, corresponding to about 280 respondents per unit. Approximately 10\% refused to participate in the survey among those approached.

Statistics: A cross-sectional study was carried out (Kesmodel, 2018). Descriptive and inferential analyses were performed using sociodemographic data and knowledge about the medication.

Bivariate analyses of each medication knowledge variable estimated the crude odds ratio (cOR) between people who had or did not have knowledge about the medication. The dependent variables used individually were knowing the name, knowing how to use it, changing the prescribed amount, thinking that one knows what the medicine is for, and actually knowing what the medicine is for. All of them had a binary YES or NO answer. The independent variables used were sociodemographic (age, schooling, and gender).

Then, a logistic regression model was developed with each of the dependent variables, simultaneously considering the association with the independent sociodemographic variables, and the results were presented as adjusted odds ratio (aOR). The significance level adopted was 5\%. All analyses were performed using STATA software (version 12.0).

Ethics: The research was submitted to the Research Ethics Committee at UNIFESP and approved under Opinion $\mathrm{N}^{\circ}$ 0618/08.

\section{Results}

Table 1 presents the sociodemographic data of the study participants (age, gender, schooling). Looking at the table it is possible to notice that women appear in a much higher percentage than men and there is a low percentage of illiterates. 
Table 1. Sociodemographic data of the 1121 respondents.

\begin{tabular}{|c|c|c|c|}
\hline Variables & Categories & $\mathbf{n}$ & $\%$ \\
\hline \multirow{7}{*}{ Age (years) } & $<18$ & 55 & 4.9 \\
\hline & $19-30$ & 201 & 17.9 \\
\hline & $31-40$ & 192 & 17.1 \\
\hline & $41-50$ & 181 & 16.2 \\
\hline & $51-60$ & 202 & 18.0 \\
\hline & $>60$ & 290 & 25.9 \\
\hline & Total & 1121 & 100.0 \\
\hline \multirow{3}{*}{ Gender } & Male & 348 & 31.0 \\
\hline & Female & 773 & 69.0 \\
\hline & Total & 1121 & 100.0 \\
\hline \multirow{5}{*}{ Schooling } & Illiterate & 59 & 5.3 \\
\hline & Elementary & 531 & 47.4 \\
\hline & High school & 496 & 44.3 \\
\hline & University & 35 & 3.1 \\
\hline & Total & 1121 & 100.0 \\
\hline \multirow{5}{*}{ PHC } & Eldorado & 345 & 30.8 \\
\hline & Pq. Real & 249 & 22.2 \\
\hline & Pq Reid & 282 & 25.2 \\
\hline & São José & 245 & 21.9 \\
\hline & Total & 1121 & 100.0 \\
\hline
\end{tabular}

Source: Authors.

The sociodemographic data show that the sample mainly consists of people over the age of $40(60.1 \%)$, with those over 50 making up the highest percentage (43.9\%). Most are women (about $70 \%$ ) with a low level of education (47.4\% have only elementary school), and the percentage of illiterates $(5.3 \%)$ and those with higher education (3.1\%) in the sample is negligible. The sample was evenly distributed among the different UBS.

Table 2 presents descriptive analysis of prescription knowledge variables among interviewed. Looking at the table it is possible to notice that the most of the sample knew the reason why the drug was prescribed. 
Table 2. Descriptive analysis of prescription knowledge variables among the 1121 respondents.

\begin{tabular}{|c|c|c|c|}
\hline Variables & Categories & $\mathbf{n}$ & $\%$ \\
\hline \multirow{3}{*}{ Knows the medication's name } & No & 494 & 44.1 \\
\hline & Yes & 627 & 55.9 \\
\hline & Total & 1121 & 100.0 \\
\hline \multirow{3}{*}{$\begin{array}{l}\text { Knows why he/she is going } \\
\text { to use it }\end{array}$} & No & 86 & 7.7 \\
\hline & Yes & 1035 & 92.3 \\
\hline & Total & 1121 & 100.0 \\
\hline \multirow{3}{*}{$\begin{array}{l}\text { He/she actually knew why } \\
\text { he/she was going to use it } \\
\text { (authors' evaluation) }\end{array}$} & Didn't know & 222 & 19.8 \\
\hline & Knew & 899 & 80.2 \\
\hline & Total & 1121 & 100.0 \\
\hline \multirow{3}{*}{ Knows how to use it } & No & 155 & 13.8 \\
\hline & Yes & 966 & 86.2 \\
\hline & Total & 1121 & 100.0 \\
\hline \multirow{4}{*}{$\begin{array}{l}\text { Knows whether it can cause } \\
\text { Problems }\end{array}$} & Doesn't know & 803 & 71.6 \\
\hline & Yes, it cannot & 234 & 20.9 \\
\hline & Yes, it can & 84 & 7.5 \\
\hline & Total & 1121 & 100.0 \\
\hline \multirow{3}{*}{$\begin{array}{l}\text { He/she asked about adverse } \\
\text { Reactions }\end{array}$} & No & 737 & 92.0 \\
\hline & Yes & 64 & 8.0 \\
\hline & Total & 801 & 100.0 \\
\hline \multirow{3}{*}{$\mathrm{He} /$ she changes dosage } & No & 1007 & 89.8 \\
\hline & Yes & 114 & 10.2 \\
\hline & Total & 1121 & 100.0 \\
\hline
\end{tabular}

Source: Authors.

Almost half of the sample did not know the name of the drug (Table 2). Respondents were asked to provide the medication name, which the researcher then checked in the medical prescription made available by the patients. Most of the sample $(92.3 \%)$ claimed they knew why they were using the medication, whereas a small percentage of the sample $(7.7 \%)$ confessed to not knowing why they were taking the medication. However, when the researchers analyzed these responses, comparing the medication obtained from the doctor's prescription with the information given by the patient, the percentage of those who did not know hiked to almost $20 \%$ (Table 2).

About $14 \%$ assumed they did not know how to use the medication despite having received a prescription from a doctor. Approximately $71 \%$ declared that they were unaware of the potential adverse drug reactions, but those who declared otherwise $(20.9 \%)$ were categorical and believed that the drug could not cause any adverse reaction. Only $7.7 \%$ considered the possibility that the drug could cause some adverse effects. When asked whether they questioned the doctor about the possibility of side effects caused by the drug, almost the entire sample (92\%) claimed not to have done so on the subject (Table 2). 
Concerning changing the prescribed dosage, that is, modifying the daily prescribed amount, $10 \%$ claimed to change the dosage due to some circumstances such as forgetting to consume the drug at a particular time, leaving it to be consumed twice in the subsequent uptake (Table 2).

Table 3 presents descriptive, bivariate, and logistic regression analysis for knowledge about the name of the medication and sociodemographic variables among the interviewed. The data show that women remember the name of the medication more easily than men.

Table 3. Descriptive, bivariate, and logistic regression analysis for knowledge about the name of the medication and sociodemographic variables among the 1121 respondents.

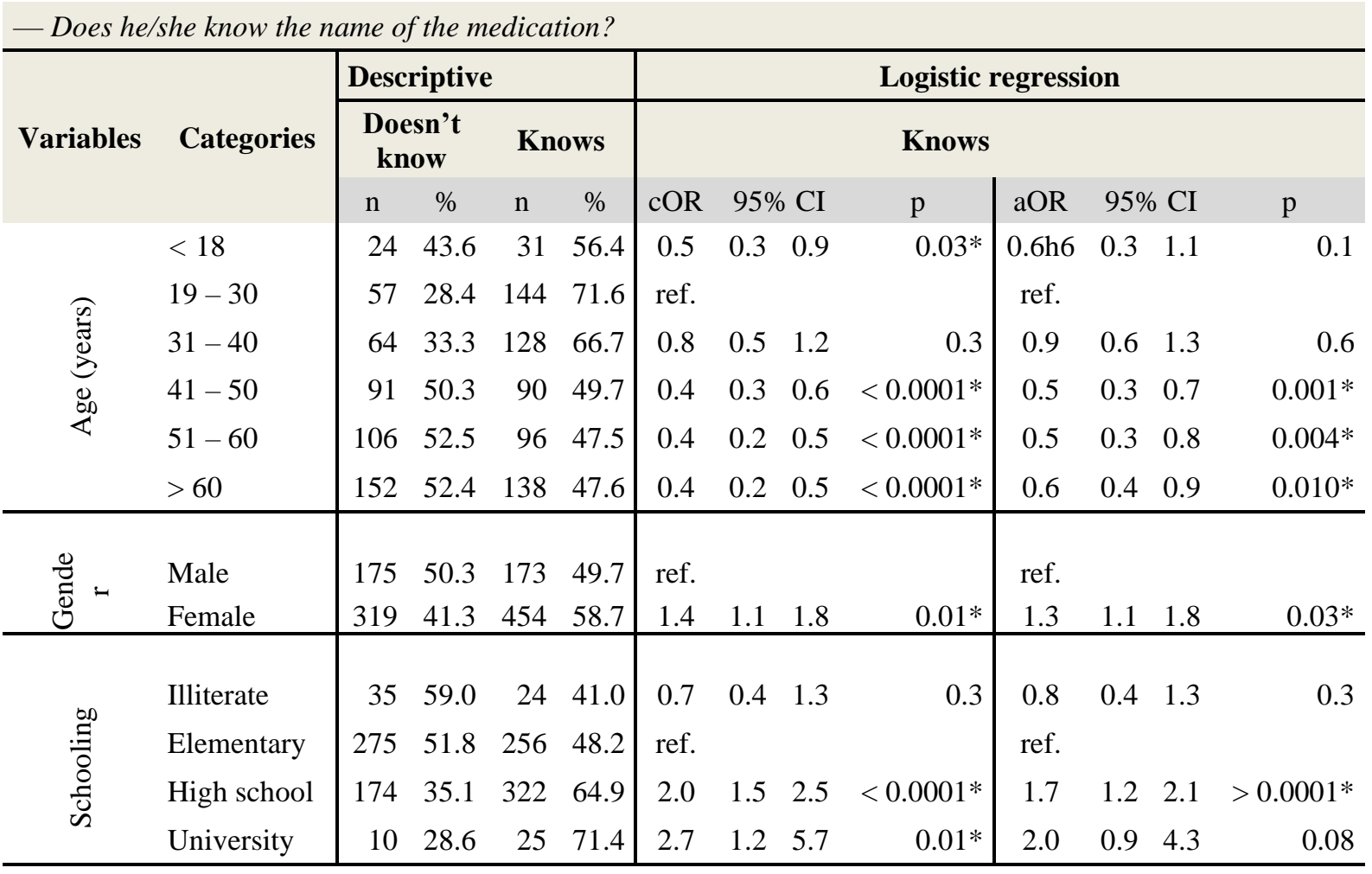

Source: Authors.

The following results are obtained when comparing the answers concerning knowledge knows the name of the medication (Table 3) with the demographic variables: Women are 30\% more likely to know the name of the drug than men are; adults over 41 are about $50 \%$ less likely to know the name compared to adults under 30 years of age. This likelihood decreases with age. Respondents with high school education are $70 \%$ more likely to know the name when compared to the less educated. This knowledge grows with schooling (Table 3).

Table 4 presents descriptive, bivariate, and logistic regression analysis for knowledge about why the interviewed will use the medication and sociodemographic variables among the respondents. It is important to notice that again the woman performs better than the man when asked if she knows why the medication was prescribed. 
Table 4. Descriptive, bivariate, and logistic regression analysis for knowledge about why he/she will use the medication (do you know why you will use the drug?) and sociodemographic variables among the 1121 respondents.

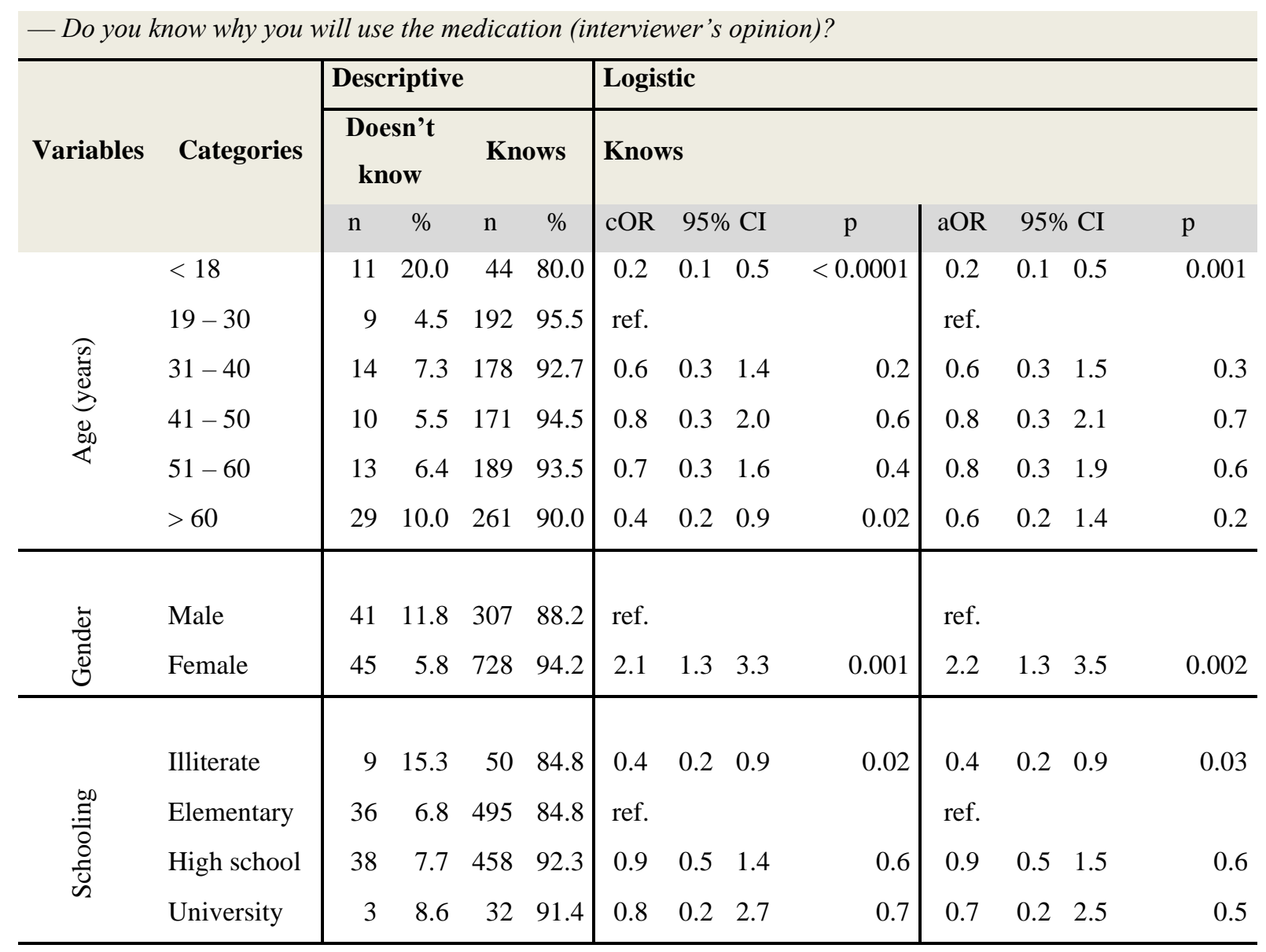

Source: Authors.

When comparing the answer to the question, do you know why you will use the medication? (Table 4) concerning sociodemographic variables, again, women are 2.2 times more likely to state that they know the reason for using the medication than men. Schooling also influences this knowledge, showing that illiterate people are $30 \%$ less likely to say they know the reason than those with higher education. Age also influences the response, and older people are more likely to assure that they know the indication of the medication when compared to younger people (Table 4).

Table 5 presents descriptive, bivariate, and logistic regression analysis for knowledge of whether the respondent actually knows the reason for using the medication and sociodemographic variables among the respondents. When the researchers analyze the answer given in the previous table, that is, if the interviewees really know the reason why the medication was prescribed, the young people showed a greater lack of knowledge than the older ones. 
Table 5. Descriptive, bivariate, and logistic regression analysis for knowledge of whether the respondent actually knows the reason for using the medication (do you actually know why you will use the medication?) and sociodemographic variables among the 1121 respondents.

\begin{tabular}{|c|c|c|c|c|c|c|c|c|c|c|c|}
\hline \multicolumn{12}{|c|}{ - Really knows why he/she is going to use the medication } \\
\hline \multirow{3}{*}{ Variables } & \multirow{3}{*}{ Categories } & \multicolumn{4}{|c|}{ Descriptive } & \multicolumn{6}{|c|}{ Logistic Regression } \\
\hline & & \multicolumn{2}{|c|}{$\begin{array}{l}\text { Doesn't } \\
\text { know }\end{array}$} & \multicolumn{2}{|c|}{ Knows } & \multicolumn{5}{|c|}{ Knows } & \multirow[b]{2}{*}{$\mathrm{p}$} \\
\hline & & $\mathrm{n}$ & $\%$ & $\mathrm{n}$ & $\%$ & $\mathrm{cOR}$ & $95 \% \mathrm{CI}$ & $\mathrm{p}$ & $\mathrm{aOR}$ & $95 \% \mathrm{CI}$ & \\
\hline \multirow{6}{*}{ 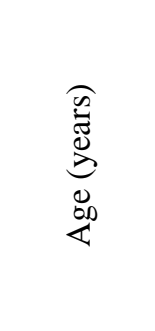 } & $<18$ & 19 & 34.6 & 36 & 65.4 & 0.5 & 0.20 .9 & 0.02 & 0.5 & 0.31 .0 & 0.05 \\
\hline & $19-30$ & 39 & 19.4 & 162 & 80.6 & ref. & & & ref. & & \\
\hline & $31-40$ & 38 & 19.8 & 154 & 80.2 & 1.0 & $0.6 \quad 1.6$ & 0.9 & 1.0 & $\begin{array}{ll}0.6 & 1.7\end{array}$ & 0.8 \\
\hline & $41-50$ & 36 & 19.9 & 145 & 80.1 & 1.0 & $0.6 \quad 1.6$ & 0.9 & 1.1 & $0.7 \quad 1.9$ & 0.7 \\
\hline & $51-60$ & 30 & 14.8 & 172 & 85.2 & 1.4 & $0.8 \quad 2.3$ & 0.2 & 1.7 & 1.13 .3 & 0.03 \\
\hline & $>60$ & 60 & 20.7 & 230 & 79.3 & 0.9 & $0.6 \quad 1.4$ & 0.7 & 1.4 & $0.8 \quad 2.4$ & 0.2 \\
\hline \multirow{2}{*}{$\begin{array}{l}\dot{\bar{\theta}} \\
\overline{0} \\
0\end{array}$} & Male & 76 & 21.8 & 272 & 78.1 & ref. & & & ref. & & \\
\hline & Female & 146 & 18.9 & 627 & 81.1 & 1.2 & 0.9 & 0.2 & 1.4 & $\begin{array}{ll}1.0 & 1.9\end{array}$ & 0.07 \\
\hline \multirow{4}{*}{$\begin{array}{l}\infty \\
: \Xi \\
0 \\
0 \\
\frac{0}{0} \\
\tilde{D}\end{array}$} & Illiterate & 20 & 33.9 & 39 & 66.1 & 0.5 & $0.3 \quad 0.9$ & 0.01 & 0.4 & $0.2 \quad 0.8$ & 0.005 \\
\hline & Elementary & 105 & 19.8 & 426 & 80.2 & ref. & & & ref. & & \\
\hline & High school & 91 & 18.3 & 405 & 81.7 & 1.1 & $0.8 \quad 1.5$ & 0.6 & 1.3 & $0.9 \quad 1.9$ & 0.1 \\
\hline & University & 6 & 17.1 & 29 & 82.9 & 1.2 & $0.5 \quad 2.9$ & 0.7 & 1.4 & $0.6 \quad 3.7$ & 0.4 \\
\hline
\end{tabular}

Source: Authors.

When evaluating whether the answer to the previous question is valid, that is, if the patient really knows the reason why he is going to use the medication (Table 5), and confronting it with the various sociodemographic variables, we find that younger people ( $<18$ years old) are $50 \%$ less likely to really know the medication they are using. In comparison, those $>51$ years old are $30 \%$ more likely than those under 40 years old to really know why. Illiterate people have their likelihood reduced when compared to adults with higher education.

Table 6 presents descriptive, bivariate, and logistic regression analysis for knowledge about how to use the medication and sociodemographic variables among the interviewed. It is important to highlight that in this case, the women demonstrated that they were more likely to make an adequate use of the drug.

Table 6. Descriptive, bivariate, and logistic regression analysis for knowledge about how to use the medication and sociodemographic variables among the 1121 respondents. 


\begin{tabular}{|c|c|c|c|c|c|c|c|c|c|c|c|c|c|}
\hline \multirow{3}{*}{ Variables } & \multirow{3}{*}{ Categories } & \multicolumn{4}{|c|}{ Descriptive } & \multicolumn{8}{|c|}{ Logistic } \\
\hline & & \multicolumn{2}{|c|}{$\begin{array}{c}\text { Doesn't } \\
\text { know }\end{array}$} & \multicolumn{2}{|c|}{ Knows } & \multicolumn{8}{|c|}{ Knows } \\
\hline & & $\mathrm{n}$ & $\%$ & $\mathrm{n}$ & $\%$ & $\mathrm{cOR}$ & $95 \%$ & CI & $\mathrm{p}$ & $\mathrm{aOR}$ & $95 \%$ & $\mathrm{CI}$ & $\mathrm{p}$ \\
\hline \multirow{6}{*}{ 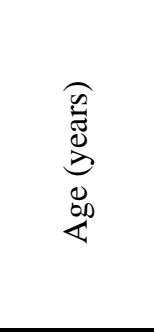 } & $<18$ & 8 & 14.6 & 47.0 & 85.5 & 0.8 & 0.3 & 1.9 & 0.6 & 0.8 & 0.3 & 2.0 & 0.7 \\
\hline & $19-30$ & 24 & 11.9 & 177.0 & 88.1 & & & & & ref. & & & \\
\hline & $31-40$ & 43 & 22.4 & 149.0 & 77.6 & 0.5 & 0.3 & 0.8 & 0.007 & 0.5 & 0.3 & 0.8 & 0.008 \\
\hline & $41-50$ & 16 & 8.8 & 165.0 & 91.2 & 1.4 & 0.7 & 2.7 & 0.3 & 1.6 & 0.8 & 3.1 & 0.2 \\
\hline & $51-60$ & 17 & 8.4 & 185.0 & 91.6 & 1.5 & 0.8 & 2.8 & 0.2 & 1.8 & 0.9 & 3.7 & 0.1 \\
\hline & $>60$ & 47 & 16.2 & 243.0 & 83.8 & 0.7 & 0.4 & 1.2 & 0.2 & 1.1 & 0.6 & 2.0 & 0.8 \\
\hline \multirow{2}{*}{ 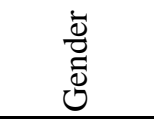 } & Male & 82 & 23.6 & 266 & 76.4 & ref. & & & & ref. & & & \\
\hline & Female & 73 & 9.4 & 700 & 90.6 & 3.0 & 2.1 & 4.2 & $<0.0001$ & 3.3 & 2.3 & 4.9 & $<0.0001$ \\
\hline \multirow{4}{*}{$\begin{array}{l}\stackrel{0}{\Xi} \\
: 0 \\
0 \\
\frac{0}{0} \\
\mathscr{n}\end{array}$} & Illiterate & 8 & 13.5 & 51 & 86.5 & 0.9 & 0.4 & 2.0 & 0.8 & 0.8 & 0.3 & 1.7 & 0.5 \\
\hline & Elementary & 65 & 12.2 & 466 & 87.8 & ref. & & & & ref. & & & \\
\hline & High school & 76 & 15.3 & 420 & 84.7 & 0.8 & 0.5 & 1.1 & 0.2 & 0.9 & 0.6 & 1.4 & 0.7 \\
\hline & University & 6 & 17.1 & 29 & 82.9 & 0.7 & 0.3 & 1.7 & 0.4 & 1.1 & 0.4 & 3.0 & 0.9 \\
\hline
\end{tabular}

Source: Authors.

When analyzing the answer to the question knows how to use the medication (Table 6) against the sociodemographic variables, we find that, again, women are more likely than men to use the medication properly, while the 31-40 age group are less likely to use it properly when compared to the younger age groups.

Table 7 presents descriptive, bivariate, and logistic regression for knowledge changes the prescribed dosages. Looking at the table it is possible to notice that younger people are more likely not to change the dosage prescribed by the doctor

Table 7. Descriptive, bivariate, and logistic regression analysis for knowledge changes the prescribed dosage and sociodemographic variables among the 1121 respondents.

— Do you change the prescribed dosage?

\begin{tabular}{|l|l|l}
\hline Variables Categories & Descriptive & Logistic \\
\cline { 2 - 3 }
\end{tabular}




\begin{tabular}{|c|c|c|c|c|c|c|c|c|c|c|c|c|}
\hline & & \multicolumn{2}{|c|}{$\begin{array}{l}\text { Doesn't } \\
\text { change }\end{array}$} & \multicolumn{2}{|c|}{ Changes } & \multicolumn{7}{|c|}{ Changes } \\
\hline & & $\mathrm{n}$ & $\%$ & $\mathrm{n}$ & $\%$ & cOR & $95 \%$ & CI & $\mathrm{p}$ & $\mathrm{aOR}$ & $95 \%$ CI & $\mathrm{p}$ \\
\hline \multirow{6}{*}{ 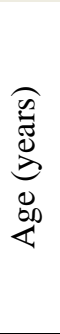 } & $<18$ & 50 & 90.9 & 5 & 9.1 & 1.4 & 0.5 & 4.2 & 0.5 & 1.4 & $0.5 \quad 4.1$ & 0.6 \\
\hline & $19-30$ & 188 & 93.5 & 13 & 6.5 & & & & & ref. & & \\
\hline & $31-40$ & 183 & 95.3 & 9 & 4.7 & 0.7 & 0.3 & 1.7 & 0.4 & 0.6 & $0.3 \quad 1.5$ & 0.3 \\
\hline & $41-50$ & 164 & 90.6 & 17 & 9.4 & 1.5 & 0.7 & 3.2 & 0.3 & 1.3 & $0.6 \quad 2.8$ & 0.5 \\
\hline & $51-60$ & 164 & 81.2 & 38 & 18.8 & 3.4 & 1.7 & 6.5 & $<0.0001$ & 3.0 & 1.46 .1 & 0.003 \\
\hline & $>60$ & 258 & 89.0 & 32 & 11.0 & 1.8 & 0.9 & 3.5 & 0.1 & 1.6 & $0.8 \quad 3.5$ & 0.2 \\
\hline \multirow{2}{*}{$\begin{array}{l}\dot{\vec{\theta}} \\
\overrightarrow{0} \\
\dot{0}\end{array}$} & Male & 308 & 88.5 & 40 & 11.5 & ref. & & & & ref. & & \\
\hline & Female & 699 & 90.4 & 74 & 9.6 & 0.8 & 0.5 & 1.2 & 0.3 & 0.9 & $0.6 \quad 1.4$ & 0.7 \\
\hline \multirow{4}{*}{$\begin{array}{l}\stackrel{00}{\Xi} \\
: 0 \\
0 \\
0 \\
0 \\
\tilde{n}\end{array}$} & Illiterate & 58 & 98.3 & 1 & 1.7 & 0.1 & 0.0 & 0.8 & 0.029 & 0.1 & $0.0 \quad 0.7$ & 0.020 \\
\hline & Elementary & 458 & 86.3 & 73 & 13.8 & ref. & & & & ref. & & \\
\hline & High school & 459 & 92.5 & 37 & 7.5 & 0.5 & 0.3 & 0.8 & 0.001 & 0.7 & $0.4 \quad 1.1$ & 0.1 \\
\hline & University & 32 & 91.4 & 3 & 8.6 & 0.6 & 0.2 & 2.0 & 0.4 & 1.1 & $0.3 \quad 4.0$ & 0.9 \\
\hline
\end{tabular}

Source: Authors.

When evaluating the answer to the question changes the prescribed dosage (Table 7), we find that the 51-60 years age group is more likely to change the dosage than younger groups. On the other hand, schooling affects inversely, that is, the higher the level of education, the more likely the change of dosage; that is, those who have completed high school are more likely to change the dosage than those with primary education. In contrast, illiterate people are less likely to change the dosage than those in elementary school.

\section{Discussion}

The results show an inadequate level of health literacy in the studied population. A troubling reality is that we are faced with at least half of the sample not knowing the name of the prescribed drug, 20\% of respondents not knowing why they are using the medication, $14 \%$ not knowing how to use it, $71 \%$ saying they were unaware of the medication's adverse effects, almost the entire sample not asking the doctor about these effects, and $10 \%$ of the sample confessing to changing the dosage. This study also shows that the level of information about the medication varies with gender, age, and schooling.

It is essential to highlight that in some of the situations analyzed (knows the name of the drug, knows the reason for using the drug, knows how to use the drug), women showed better health literacy than men. Other studies also show women's knowledge of the basic information about the medication and attribute this framework to norms related to gender, which interfere in the search for health care and the behavior vis-à-vis this care (Hibbard and Popw, 1987). Male rules disproportionately affect men who adopt a cultural script in which they regard health behaviors as non-male, leading them to opt for the image of resistance and invincibility over personal well-being (Wiginton et al.,2019).

In contrast, women are the "responsible for primary care" within their family, deciding on health care related to family members. In the U.S., for example, it is estimated that $80 \%$ of women make health decisions for their family members and are "primary caregivers" when a family member is ill. These factors contribute to a more adequate health literacy than men (Lee et al., 2012).

Low schooling or even illiteracy hinders understanding a prescription that requires the help of a health professional to overcome this difficulty (Wittink and Oosterhaven, 2018). In the sample of this study, the results lead us to infer that this support 
was flawed or lacking, revealing a deficient interaction between health professionals and patients. On the other hand, studies have shown that patients with low socioeconomic status and schooling and those who are a minority ask few questions regarding the explanations of the health professional, which translates into a failing communication (Matsuyama et al, 2011). However, this situation may be linked to the SUS large demand, which results in long waiting times and short time dedicated to the patient in the medical visit, harming the patient-health professional relationship.

According to the study, the medication name is more likely to be mastered by women. Higher education also contributed to acquiring this knowledge, but older people are less likely to remember the name (Wali et al, 2017; Delavar et al, 2020). An observation should be made regarding the name of the medication used in the public service, in which the generic name of the active ingredient is prescribed by the doctor avoiding the brand name, which may hinder memorization.

Dosage change is another result that must be considered because the partial or total non-compliance of the dosage regimen is one of the main barriers to effective drug treatment, especially chronic use medication, leading to aggravations with negative repercussions on the user's quality of life and increased costs to the health system (Falgas-Bague et al., 2019). However, this finding draws attention to the discovery that this change is made mainly by those with a higher level of education, which is not aligned with the general consensus that warns that low education interferes negatively with the understanding of the prescription. The authors propose a hypothesis for this result based on the findings of the Matsuyama et al (2011), who cast doubt over the level of education being a decisive parameter for evaluating health literacy. According to these authors, the patient's health-related skills and information about the medication can offset the low level of education more than schooling. One possibility would be that less educated patients would consider the information received from the health professional regarding the medication as the only way to avoid drug administration mistakes, and, in that case, they tend to follow it more strongly. The more educated may feel more confident in changing the dosage based on erroneous self-defined premises, such as forgetting to take one medication may be compensated by administering twice the dosage on the subsequent uptake (Visscher et al, 2021).

Another important finding that should be commented on is that only $7.7 \%$ of the sample claimed not knowing the reason for using the medication, but when the answer was confronted with the medication's indications, that percentage rose to $20 \%$, but even so, a high percentage of the sample (about 80\%) knew the reason why they were using the medication. Other authors also found an appropriate level regarding this item, with patients attributing this knowledge to the fact that the reason for using the medication was what led them to seek a health professional (Portela et al, 2010).

Another revealing fact is that the participants of the higher age range had a better performance than the younger ones concerning knowledge of the indication of the medicine. This finding casts doubt over the general belief that older people have little understanding of the purpose of medicine. Guénette and Moison (2011) found similar data but recommended that, along with age, some parameters be evaluated, such as gender, cognition, and the number of medications taken. Another hypothesis to be considered is that older people use chronic use drugs, which inevitably leads them to have a more profound knowledge of the medication due to its prolonged use.

Finally, and quite worryingly, $92 \%$ of the sample were unaware of the potential adverse effects of the drug or did not ask the doctor about them. Those who knew them claimed that the drug would not harm them. Two possibilities can be inferred from this result. The little appreciation that doctors give to this information, to the point of not clarifying the patient about the fact. Some authors believe that this occurs because doctors are afraid that patients would not adhere to the medication if they were informed of its possible adverse reactions (Auchewski et al., 2004). The other possibility is the poor health professionalpatient interaction (Olsson et al., 2017).

\section{Conclusion}


The data show an inadequate level of health literacy of SUS users concerning underlying information about the prescribed medicine and potential risk from its misuse, considering the patient's lack of familiarity with the medication and its pathology (does not know the name, does not know for what reason it was prescribed, dosage change, lack of knowledge on the adverse reactions). As detected in the study, the lack of a better interaction with the healthcare professional may have negatively affected the transmission of the information about the prescribed medication. However, it should be noted that some sociodemographic variables interfere with the level of health literacy, such as gender, schooling level, and age. The importance of health literacy in treatment adherence and rational use of medications strongly indicates that further studies should be performed in other populations, such as those belonging to higher social classes.

\section{References}

Alshammari, T. M. (2016). Patient's medicinal knowledge in Saudi Arabia: Are we doing well? Saudi Pharm J, 24(5):560-562. 10.1016/j.jsps.2015.03.014.

Andrade, S. M., Cunha, M. A., Holande, E. C., Verde R. M. C. L., \& Oliveira, E. H. (2020). Characterization of the profile of drug intoxications by selfmedication in Brazil, from 2010 to 2017. Research, Society and Development, 9:1-16. 10.33448/rsd-v9i7.3952.

Araújo, A. L, Pereira, L. R., Ueta, J. M., \& Freitas, O. (2008). Pharmacist care in the Brazilian primary health care system. Cien Saude Colet., 13(6):11-7. $10.1590 / \mathrm{s} 1413-81232008000700010$.

Auchewsk, i L., Andreatini, R., Galduróz, J. C., Lacerda, R. B. (2004). Evaluation of the medical orientation for the benzodiazepine side effects. Braz J Psychiatry, 26(1):24-31. 10.1590/s1516-44462004000100008.

Bastos A. (2021). Desempregomantémrecorde de 14,7\% notrimestreencerradoemabril. Disponível em: https://agenciadenoticias.ibge.gov.br/agencia-noticias/2012-agencia-denoticias/noticias/31050-desemprego-mantem-recorde-de-14-7-no-trimestre-encerrado-em-abril. Acessado em: 04 de agosto de 2121.

Bosch-Lenders, D., Maessen, D. W., Stoffers, H. E., Knottnerus, J. A., Winkens, B., \& van den Akker, M. (2016). Factors associated with appropriate knowledge of the indications for prescribed drugs among community-dwelling older patients with polypharmacy. Age Ageing, 45(3):402-8. 10.1093/ageing/afw045.

Cajita, M. I., Cajita, T. R., \& Han, H. R (2016). Health Literacy and Heart Failure: A Systematic Review. J Cardiovasc Nurs, 31(2):121-30. 10.1097/JCN.0000000000000229.

Calikoglu, E. O., Köyceğiz, E., Kosan, Z., \& Aras, A. (2019). Rational drug use and prescribing behavior of family physicians in Erzurum, Turkey. Niger J Clin Pract. 22:626-32. 10.4103/njcp.njcp_258_18.

Castro, M. C., Massuda, A., Almeida, G., Menezes-Filho, N. A., Andrade, M. V., Souza Noronha, K. V. M., Rocha, R., Macinko, J., Hone, T., Tasca, R., Giovanella, L., Malik, A. M., Werneck, H., \& Fachini, L. A., Atun, R. (2019). Brazil's unified health system: the first 30 years and prospects for the future. Lancet, 394(10195):345-356. 10.1016/S0140-6736(19)31243-7.

Delavar, F., Pashaeypoor, S., \& Negarandeh, R. (2020). The effects of self-management education tailored to health literacy on medication adherence and blood pressure control among elderly people with primary hypertension: A randomized controlled trial. Patient Educ Couns, 103(2):336-342. 10.1016/j.pec.2019.08.028.

Dunn, P., \& Conard S. (2018). Improving health literacy in patients with chronic conditions: A call to action. Int J Cardiol, 15;273:249-251. 10.1016/j.ijcard.2018.08.090.

Falgas-Bague, I., Wang, Y., Banerjee, S., Ali, N., DiMarzio, K., Palao, Vidal, D., \& Alegría, M. (2019). Predictors of Adherence to Treatment in Behavioral Health Therapy for Latino Immigrants: The Importance of Trust. Front Psychiatry, 10:817. 10.3389/fpsyt.2019.00817.

Guénette, L., \& Moisan, J. (2011). Elderly people's knowledge of the purpose of their medicines. Am J Geriatr Pharmacother. 9(1):49-57. 10.1016/j.amjopharm.2011.02.007.

Hersh, L., Salzman, B., \& Snyderman, D. (2015). Health Literacy in Primary Care Practice. Am Fam Physician, 92(2):118-24. PMID: 26176370.

Hibbard, J. H.. \& Pope, C. R. (1987). Women's roles, interest in health and health behavior. Women Health, 12(2):67-84. 10.1300/J013v12n02_05.

IBGE (2010) Instituto Brasileiro de Gogrfia e Estatística. Indice de Desenvolvimento Humano. https://www.ibge.gov.br/busca.html?searchword=diadema+IDH.

Johnson, J. L., Moser, L., \& Garwood, C. L. (2013). Health literacy: a primer for pharmacists. Am J Health Syst Pharm 70(11):949-55. 10.2146/ajhp120306.

Kesmodel, U. S. (2018). Cross-sectional studies - what are they good for? Acta Obstet Gynecol Scand, 97(4):388-393. 10.1111/aogs.13331

Lee, S. Y., Tsai, T. I., Tsa,i Y. W., \& Kuo, K. N. (2012). Health literacy and women's health-related behaviors in Taiwan. Health Educ Behav, 39(2):210-8. $10.1177 / 1090198111413126$.

Marciano, L., Camerini, A. L., \& Schulz, P. J (2019). The Role of Health Literacy in Diabetes Knowledge, Self-Care, and Glycemic Control: a Meta-analysis. J Gen Intern Med, 34(6):1007-1017. 10.1007/s11606-019-04832-y

Massuda, A. (2020). Primary health care financing changes in the Brazilian Health System: advance ou setback? Cien Saude Colet, 25(4):1181-1188. 10.1590/1413-81232020254.01022020. 
Massuda, A., Hone, T., Leles, F. A. G., Castro, M. C., \& Atun, R. (2018). The Brazilian health system at crossroads: progress, crisis and resilience. BMJ Glob Health, 3(4):e000829. 10.1136/bmjgh-2018-000829.

Matsuyam, a R. K, Wilson-Genderson, M., Kuhn, L., Moghanaki, D., Vachhani, H., \& Paasche-Orlow, M. (2011). Education level, not health literacy, associated with information needs for patients with cancer. Patient Educ Couns, 85(3):e229-36. A cross-sectional study was carried out (Kesmodel, 2018)10.1016/j.pec.2011.03.022

Mendez, L. C., Moraes, F. Y., Fernandes, G. D. S., \& Weltman, E. (2018). Cancer Deaths due to Lack of Universal Access to Radiotherapy in the Brazilian Public Health System. Clin Oncol (R Coll Radiol), 30(1):e29-e36. 10.1016/j.clon.2017.09.003.

Oliveira, L. H., de Mattos, R. A., \& Souza, A. I. (2009). Travelling citizens: the 'users' of the Brazilian Unified Health System and the meanings of its demand to the health care emergency services in the context of a process of assistential model reorientation. Cien Saude Colet, 14(5):1929-38. 10.1590/s141381232009000500035

Olsson, E., Wallach-Kildemoes, H., Ahmed, B., Ingman, P., Kaae, S., \& Kälvemark Sporrong, S. (2017). The influence of generic substitution on the content of patient-pharmacist communication in Swedish community pharmacies. Int J Pharm Pract, 25(4):274-281. 10.1111/ijpp.12299.

Pasternak, J. (2018). What is the future of the Brazilian Public Health System? Einstein (Sao Paulo), 16(4):eED4811. 10.31744/einstein_journal/2018ED4811.

Parnell, T. A., Stichler, J. F., Barton, A. J., Loan, L. A., Boyle, D. K., \& Allen, P. E. (2019). A concept analysis of health literacy. Nurs Forum, 4(3):315-327. $10.1111 /$ nuf.12331.

PNAD (2018). Parâmetros de Diadema disponível em: https://cidades.ibge.gov.br/brasil/sp/diadema/panorama. Acessado em 13 de maio de 2021.

Portela, A. S., Simões, M. O., Fook, S. M., Montenegro Neto, A. N., \& Silva, P. C. (2010). Medical prescriptions: adequate orientation to medicine use? Cien Saude Colet, 15(3):3523-8. 10.1590/s1413-81232010000900027.

Sørensen, K., Pelikan, J. M., Röthlin, F., Ganahl, K., Slonska, Z., Doyle, G., Fullam, J., Kondilis, B., Agrafiotis, D., Uiters, E., Falcon, M., Mensing, M., Tchamov, K., van den Broucke, S., Brand, H., \& HLS-EU Consortium (2015). Health literacy in Europe: comparative results of the European health literacy survey (HLS-EU). Eur J Public Health, 25(6):1053-8. 10.1093/eurpub/ckv043.

Tae, C. H., Jung, S. A., Moon, H. S., Seo, J. A., Song, H. K., Moon, C. M., Kim, S. E., Shim, K. N., \& Jung, H. K. (2016). Importance of Patients' Knowledge of Their Prescribed Medication in Improving Treatment Adherence in Inflammatory Bowel Disease. J Clin Gastroenterol, 50(2):157-62. 10.1097/MCG.0000000000000431.

Visscher, B. B., Steunenberg, B., Zwikker, H., Heerdink, E. R., \& Rademakers, J. (2021). The impact of health literacy on beliefs about medication in a Dutch medication-using population. Eur J Clin Pharmacol, 77(8):1219-1224. 10.1007/s00228-021-03105-0.

Wiginton, J. M., Fleming P. J., Barrington C., Donastorg Y., Lerebours L., Brito M. O. (2020). Masculine gender norms, male circumcision, and men's engagement with health care in the Dominican Republic. Glob Public Health, 15(5):654-665. 10.1080/17441692.2019.1704817.

Wittink H., \& Oosterhaven J. (2018). Patient education and health literacy. Musculoskelet Sci Pract, 38:120-127. 10.1016/j.msksp.2018.06.004.

Wali, H., Hudani, Z., Wali, S., Mercer, K., \& Grindrod, K. (2016). A systematic review of interventions to improve medication information for low health literate populations. Res Social Adm Pharm, 12(6):830-864. 10.1016/j.sapharm.2015.12.001.

WHO Promoting Rational use of Medicines: Core Components. WHO Policy Perspectives on Medicines. Report WHO/EDM/2002.3.2002. WHO. https://apps.who.int/iris/bitstream/handle/10665/67438/WHO_EDM_2002.3.pdf; 2002

Yevstigneev, V., Titarenko, A. F., Abakumova, T. R., Alexandrova, V. N. Khaziakhmetova, V. N., \& Ziganshina, L. E. (2015). Towards the rational use of medicines. International Journal of Risk \& Safety in Medicine, 27:S59-S60. 10.3233/JRS150690S. 